\title{
Effect of high-quality technical capacity characteristics to the impact of industrial production
}

\author{
Y.V. Lysenko ${ }^{1, *}, M . V$. Lysenko $^{1}$, and G.A. Zelenskaya ${ }^{1}$ \\ ${ }^{1}$ South Ural State University, Chelyabinsk, Russia
}

\begin{abstract}
The article deals with problems of the qualitative assessment of the technical capacity of the economic industrial organizations, in which the development of methods for assessment and management of heterogeneous quality of resources requires establishing their resultant value at any ratio of the structural elements (resources) and the definition (increase or decrease) the effectiveness of their quantitative characteristics. The extent of the qualitative assessment of the adequacy of technical capacity of industry organizations has a direct impact on the efficiency of its formation. The article made specific calculations to identify the functional relationship between the productivity of industrial production and the main characteristics of the technical capacity of industry organizations Chelyabinsk and Sverdlovsk regions. It was concluded that the negative correlation between the quantitative security technology and efficiency of industrial production - the last influence energy power technical capacity. The equations of regression, depending on the factor variable, made their forecast.
\end{abstract}

\section{Introduction}

The relevance of research topic of this article is associated with the necessary knowledge of qualitative and quantitative characteristics of the technical capacity of industry organizations, costeffective conditions of its formation, which allows managers of industrial companies to assess the effectiveness of its use and make fundamental strategic decisions.

Currently, the production process the main task performs formation of resource potential: optimizing resources and increasing the volume of industrial production. This primarily concerns the technical capacity, in which the results of scientific and technological progress have a direct mapping.

The purpose of the study - to establish the relationship between the productivity of industrial production and the main characteristics of the technical capacity of industry organizations. PURPOSE: To determine the presence and type of relationship between indicators of equipment manufacturing resources and the final results of production activities of industrial organizations Chelyabinsk and Sverdlovsk regions, in absolute, relative, specific values; determine the extent of the impact of technical equipment on the production volume, revenues and earnings; determine the functional relationships between quantitative and qualitative characteristics of the technical resources and results of operations. The subject of study is the technical potential of industrial production, the subject - industry organizations Chelyabinsk and
Sverdlovsk regions. The sample includes those industrial organizations that stably throughout the study period 2010-2014.

\section{Analysis of technical equipment}

Investigation of the effect of high-quality technical capacity at the performance characteristics of industrial production includes several stages [1, 12].

In the first stage of research revealed the technical equipment of the impact on the final results of operations, to this end, consider the following indicators:

$X_{1}$ - income (loss) from sales, mln rub.; $X_{2}$ - the revenue from sales, mln rub.; $X_{3}$ - production area, $\mathrm{m}^{2} ; X_{4}$ - production capacity at constant prices, mln rub.; $X_{5}$ - output in comparable prices, thousand rub.; $X_{6}$ - the average selling price per 1 unit, thousand rub.; $X_{7}$ - the cost of commodity products, mln rub.; $X_{8}$ - plasma installation "Agate", ed.; $X_{9}$ - plasma installation "Pella", ed.; $X_{10}-$ average number of employees, pers.

With a package of applied statistical programs based correlation matrix of the studied indicators of industrial organizations Chelyabinsk and Sverdlovsk regions in real terms. An example is shown in Table 1 .

The outcome of the industrial enterprises in 2014 revealed no direct relationship between security technology and industrial production efficiency. The correlation between these two indicators is not only weak, but also negative. 
Table 1. Correlation analysis of the main economic indicators of industrial organizations (end of 2014).

\begin{tabular}{|c|c|c|c|}
\hline $\begin{array}{l}\text { Productive } \\
\text { resources }\end{array}$ & $\begin{array}{c}\text { Profit } \\
\text { (loss) from } \\
\text { sales, } \\
\text { mln rub. } \\
\left(Y_{1}\right)\end{array}$ & $\begin{array}{l}\text { Revenues } \\
\text { from } \\
\text { sales, mln } \\
\text { rub. }\left(Y_{2}\right)\end{array}$ & $\begin{array}{c}\text { Producti } \\
\text { on } \\
\text { capacity } \\
\text { at } \\
\text { constant } \\
\text { prices, } \\
\text { mln rub. } \\
\left(Y_{3}\right) \\
\end{array}$ \\
\hline \multicolumn{4}{|c|}{ Chelyabinsk region } \\
\hline $\begin{array}{l}\text { Production area, } \\
\mathrm{m}^{2}\left(\mathrm{X}_{3}\right)\end{array}$ & -0.16 & 0.56 & 0.87 \\
\hline $\begin{array}{l}\text { The plasma unit } \\
\text { "Agate" units. } \\
\left(\mathrm{X}_{8}\right)\end{array}$ & -0.15 & 0.32 & 0.62 \\
\hline $\begin{array}{l}\text { The plasma unit } \\
\text { "Pella", ed.; }\left(\mathrm{X}_{9}\right)\end{array}$ & -0.15 & 0.39 & 0.68 \\
\hline $\begin{array}{l}\text { The average } \\
\text { number of } \\
\text { employees, pers. } \\
\left(\mathrm{X}_{10}\right)\end{array}$ & -0.18 & 0.45 & 0.74 \\
\hline \multicolumn{4}{|c|}{ Sverdlovsk region } \\
\hline $\begin{array}{l}\text { Production area, } \\
\mathrm{m}^{2}\left(\mathrm{X}_{3}\right)\end{array}$ & 0.55 & 0.68 & 0.88 \\
\hline $\begin{array}{l}\text { The plasma unit } \\
\text { "Agate" units. } \\
\left(\mathrm{X}_{8}\right)\end{array}$ & 0.60 & 0.43 & 0.74 \\
\hline $\begin{array}{l}\text { The plasma unit } \\
\text { "Pella", ed.; }\left(\mathrm{X}_{9}\right)\end{array}$ & 0.57 & 0.51 & 0.86 \\
\hline $\begin{array}{c}\text { The average } \\
\text { number of } \\
\text { employees, pers. } \\
\left(\mathrm{X}_{10}\right)\end{array}$ & 0.40 & 0.27 & 0.59 \\
\hline
\end{tabular}

The outcome of the industrial enterprises in 2014 revealed no direct relationship between security technology and industrial production efficiency. The correlation between these two indicators is not only weak, but also negative.

A significant degree of correlation observed in 2014 between the production capacity of comparable prices and security of industrial enterprises manufacturing facilities, human resources, plasma "Agate" units (the correlation coefficient ranges in the Chelyabinsk region $-0.62 \ldots 0.87$, the Sverdlovsk region $-0.59 \ldots 0.88)$. Between the proceeds from the sale of products and technical equipment, as well as between profit (loss) from production and realization of communication resources noticeable: the correlation coefficient is equal to the Chelyabinsk region $-0.15 \ldots 0.56$, the Sverdlovsk region $-0.27 \ldots$ 0.68 . Communication on the profit (loss) from sales of products is lower than the production capacity at constant prices, and revenue from sales - due to the fact that the profit (loss) from the sale of products to a greater extent influenced by external factors: selling price, conditions and market size, the debt owed to creditors, payments to the budget and off-budget funds, and so on.

Thus, the functional dependence of the production capacity at constant prices (Y) of productive resources is as follows:

Chelyabinsk region

$$
\begin{array}{r}
Y_{3}=-5339.639+5.473 X_{3}-412.561 X_{8}+719.393 X_{9}+ \\
+344.091 X_{10} \quad\left(R^{2}=0.88\right),
\end{array}
$$

Sverdlovsk region

$$
Y_{3}=-11202.833+1.331 X_{3}+83.404 X_{9},\left(R^{2}=0.89\right)
$$

In all cases, "Agate" standard error for installations Plasma deviation was significant, in this connection, the figure in the regression models was not reflected. This suggests that the impact of the amount of industrial production of plasma systems "Agat" has no direct impact.

At the second stage of the study was a hypothesis about the possible presence of a closer link between performance and specific industrial production values and an attempt was made to process than the absolute values of the indicators and their change, that is, the growth rate $[2,8,11$, $20]$. But in this case, it was confirmed by the lack of communication between the studied parameters. So, using specific parameters in the calculations, it was found that in most cases the specific outcomes of economic activity, the higher the smaller the size of the production area and following security appliances.

\section{Analysis of quality performance technical building}

The contradiction between the results obtained in the absolute and specific indicators require analysis of the impact of the qualitative characteristics of technical resources on the final economic indicators. As such, it considered the security of industrial production energy capacity (energy saturation characteristic of the process) and the degree of technological renovation of the park $[3,6$, 14, 19].

Divide data set on energy capacities of the main technology available in industrial organizations in the three intervals is shown in Fig. 1, 2.

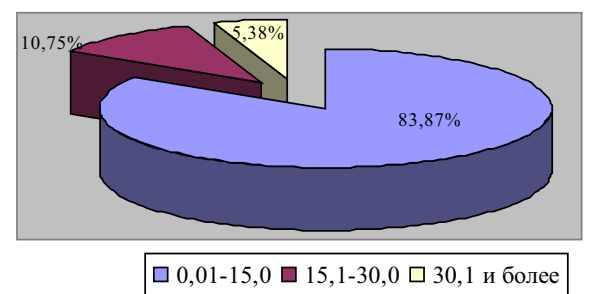

Fig. 1. Provision of industrial enterprises of the Chelyabinsk region power capacities, 2014, thousand. Hp.

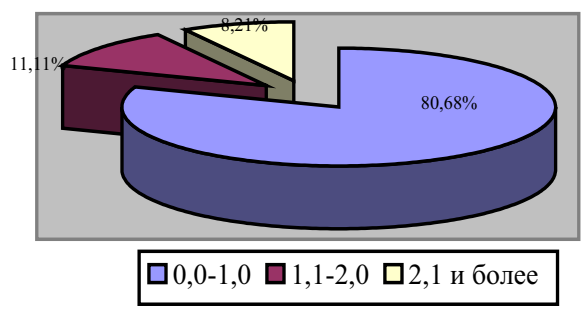

Fig. 2. Provision of industrial enterprises of the Chelyabinsk region energy capacities, in 2014, ths. KWh / person. 
Power supply of industrial enterprises in terms of cardinality from 0.01 to 15 thousand. Hp Conditionally separating industrial organizations into three groups, it was found that $83.87 \%$ of the number of all investigated companies of the Chelyabinsk region provided with equipment with a total power capacity of $0.01 \ldots 15.0$ thousand hp, $10.75 \%$ - Power appliances $15.01 \ldots 30.0$ thousand hp., $5.38 \%$ - machinery, power over 30.01 thousand hp.

On industrial organizations of Chelyabinsk Region energy facilities in th. KW / person. The situation is about the same. Only $8.21 \%$ of the industrial companies of the Chelyabinsk region to ensure energy capacity more than 2.1 ths. KWh / person.

Divide data set on energy capacities of the main technology available in the Sverdlovsk region, in the three intervals is shown in Fig. 3, 4.

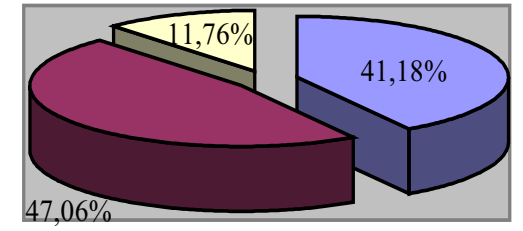

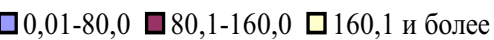

Fig. 3. Availability of industrial enterprises of the Sverdlovsk region energy capacity, $2014 \mathrm{hp}$.

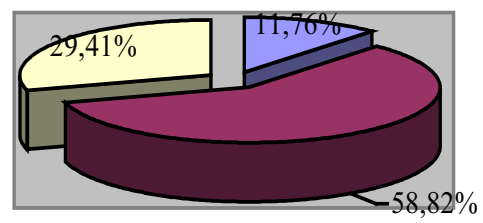

$\square$ 0,01-3,5 $\square 3,51-7,0 \square 7,1$ и более

Fig. 4. Provision of industrial enterprises of the Sverdlovsk region energy capacities, in 2014, ths. KWh / person.

Power supply industrial enterprises of Sverdlovsk region is in terms of cardinality of 80.1 to $160.0 \mathrm{hp}$ Conditionally separating industrial organizations into three groups, it was found that $47.06 \%$ of the number of all investigated areas of the Sverdlovsk region provided with equipment with a total power capacity of $80.1 \ldots 160.0 \mathrm{hp}, 41.18 \%-0.01 \ldots$ technology power $80.0 \mathrm{hp}, 11.76 \%$ - appliances, power over $160.1 \mathrm{hp}$

On industrial organizations of the Sverdlovsk region about the same installed power situation. Only $29.41 \%$ of the industrial companies of the Chelyabinsk region to ensure energy capacity more than 7.1 ths. KWh / person.

Correlation analysis of the link between technical resources in industrial companies of the Chelyabinsk region and the production area, as well as indicators of achievement (production capacity, revenues and profits from sales of products) is presented in Table. 2.

Table 2. Correlation between technical resources, production area and efficiency of industrial enterprises, 2014.

\begin{tabular}{|c|c|c|}
\hline \multirow{2}{*}{ Correlation } & \multicolumn{2}{|c|}{$\begin{array}{c}\text { Power capacity of } \\
\text { agricultural machinery }\end{array}$} \\
\hline & hp & $\begin{array}{l}\text { kWh / } \\
\text { person }\end{array}$ \\
\hline \multicolumn{3}{|c|}{ Chelyabinsk region } \\
\hline Production area, $\mathrm{m}^{2}$ & 0.69 & 0.44 \\
\hline $\begin{array}{l}\text { Production capacity at } \\
\text { constant prices, mln rub. }\end{array}$ & 0.65 & 0.50 \\
\hline $\begin{array}{l}\text { Revenues from sales, mln } \\
\text { rub. }\end{array}$ & 0.29 & 0.16 \\
\hline $\begin{array}{l}\text { Profit (loss) from sales, mln } \\
\text { rub. }\end{array}$ & 0.02 & -0.04 \\
\hline \multicolumn{3}{|c|}{ Sverdlovsk region } \\
\hline Production area, $\mathrm{m}^{2}$ & 0.57 & 0.57 \\
\hline $\begin{array}{l}\text { Production capacity at } \\
\text { constant prices, mln rub. }\end{array}$ & 0.42 & 0.50 \\
\hline $\begin{array}{l}\text { Revenues from sales, mln } \\
\text { rub. }\end{array}$ & 0.44 & 0.22 \\
\hline $\begin{array}{l}\text { Profit (loss) from sales, mln } \\
\text { rub. }\end{array}$ & 0.29 & 0.03 \\
\hline
\end{tabular}

The analysis showed that industrial activity results are determined by the energy capacity of the technical capacity $[4,13,15,21]$. Indicators for which the coefficient of the absolute value of the correlation is greater than 0.80 are multicollinearity. Thus, in 2014 has not been a close relationship between technical resources, production area and the impact of the industrial organizations.

According to the results of factor analysis using principal component analysis [5, 10, 16, 18] were identified two factors that contribute most to the total dispersion of $-60.8 \%$ (Table 3 ).

Table 3. Factor loadings of initial data.

\begin{tabular}{|c|c|c|}
\hline Variable & $\begin{array}{c}\text { Factor } \\
1\end{array}$ & $\begin{array}{c}\text { Factor } \\
2\end{array}$ \\
\hline \multicolumn{3}{|l|}{ Chelyabinsk region } \\
\hline Production capacity at constant prices & -0.876 & -0.304 \\
\hline Revenue from product sales & -0.887 & -0.304 \\
\hline Profit (loss) from sales of products & 0.305 & 0.295 \\
\hline Load one plasma unit "Agat" & -0.252 & 0.735 \\
\hline Load one plasma unit "Pella" & -0.410 & 0.560 \\
\hline $\begin{array}{l}\text { Load on one machine with numerical } \\
\text { control }\end{array}$ & -0.281 & 0.752 \\
\hline The total variance & 1.957 & 1.691 \\
\hline The proportion of the total variance & 0.326 & 0.282 \\
\hline \multicolumn{3}{|l|}{ Sverdlovsk region } \\
\hline Production capacity at constant prices & -0.941 & -0.101 \\
\hline Revenue from product sales & -0.754 & -0.298 \\
\hline Profit (loss) from sales of products & -0.657 & -0.308 \\
\hline Load one plasma unit "Agat" & -0.683 & 0.114 \\
\hline Load one plasma unit "Pella" & -0.878 & 0.036 \\
\hline $\begin{array}{l}\text { Load on one machine with numerical } \\
\text { control }\end{array}$ & -0.490 & 0.843 \\
\hline The total variance & 3.362 & 0.918 \\
\hline The proportion of the total variance & 0.560 & 0.153 \\
\hline
\end{tabular}


The calculations use absolute data on industrial organizations, describing their interest in obscheoblastnyh terms of capacity, revenue, profits from sales of products, the load on the plasma unit "Agat" plasma unit "Pella" and the machine with numerical control (CNC).

The bold color highlights those values of the studied parameters, which interprets the main components. For example, in the Chelyabinsk region, the first component is closely related to production capacity at constant prices (in the Chelyabinsk region $R^{2}=-0.876$, in the Sverdlovsk region $R^{2}=-0.941$ ), and revenue from sales of products (in the Chelyabinsk region $R^{2}=-0.887$, in the Sverdlovsk region $R^{2}=-0.754$ ), and the second component includes a load on a plasma unit "Agat" (Chelyabinsk region $R^{2}=0.735$ ) and load on a CNC machine (in the Chelyabinsk region $R^{2}=0.752$, in the Sverdlovsk region $\left.R^{2}=0.843\right)$. The first factor can be interpreted as the level of security of the Ural federal district organizations the main economic results of production activities, the second - as a provision of the technical potential. Two factors scattering diagram is displayed in Fig. 5 and 6, which show the load for each variable.

Fig. 5, 6 clearly shows that industrial activity results are not correlated with other variables.

\section{Building a regression model of dependence from factor variables}

The next step is an attempt to build a regression model was made according to the factor variables [7, 9, 17], which is selected as the load structure technology, in three scoring criteria: capacity at constant prices, million rubles. (Y1); revenue from sales, mln. (Y2); profit from sales, mln. (Y3) (tab. 4).

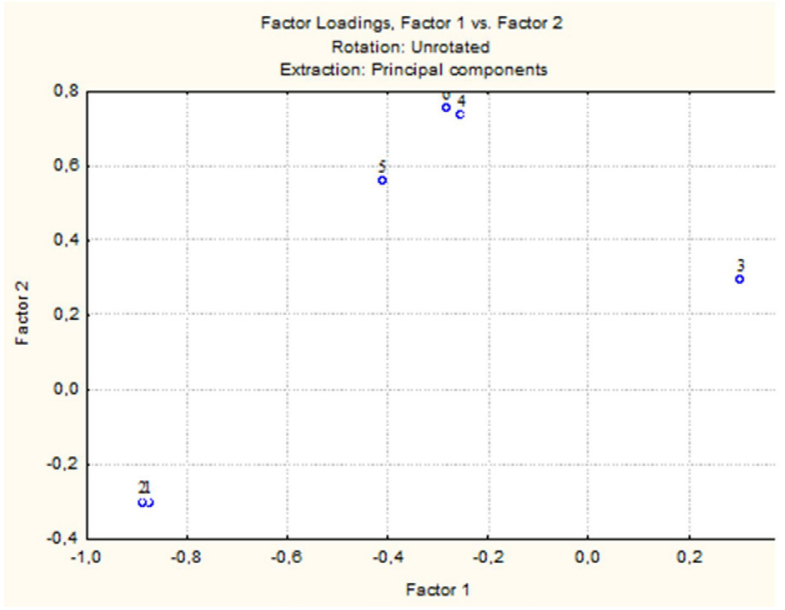

Fig. 5. Factor loadings of variables using principal component analysis for the Chelyabinsk region $(1-$ capacity at constant prices; 2 - Revenue from sales of products; 3 - Profit (loss) from sales of products; 4 - load on one plasma unit "Agat"; 5 load on one plasma unit "Pella"; 6 - the load on the CNC.).

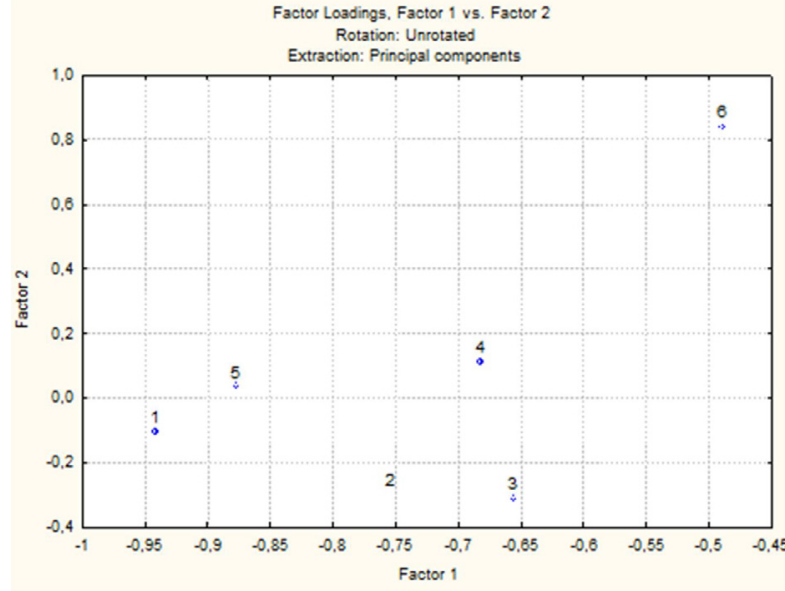

Fig. 6. Factor loadings of variables using principal component analysis for the Sverdlovsk region (1 - capacity at constant prices; 2 - Revenue from sales of products; 3 - Profit (loss) from sales of products; 4 - load on one plasma unit "Agat"; 5 load on one plasma unit "Pella"; 6 - load on one CNC).

Table 4. Significant regression coefficients of equations.

\begin{tabular}{|c|c|c|c|}
\hline $\begin{array}{c}\text { The load per unit of } \\
\text { agricultural land } \\
\text { technology }\end{array}$ & $\mathrm{Y}_{1}$ & $\mathrm{Y}_{2}$ & $\mathrm{Y}_{3}$ \\
\hline \multicolumn{4}{|c|}{ Chelyabinsk region } \\
\hline The plasma unit "Agat" & -0.632 & -0.628 & -0.632 \\
\hline The plasma unit "Pella" & 0.604 & 0.599 & 0.603 \\
\hline Machine with CNC & -0.104 & -0.096 & -0.103 \\
\hline \multicolumn{4}{|c|}{ Sverdlovsk region } \\
\hline The plasma unit "Agat" & 0.207 & 0.039 & 0.312 \\
\hline The plasma unit "Pella" & 0.645 & 0.777 & 0.331 \\
\hline Machine with CNC & 0.063 & -0.211 & -0.116 \\
\hline
\end{tabular}

According to the above Table. 4 According to the plasma installation "Agate" and $\mathrm{CNC}$ have a negative impact on the effectiveness of the signs. The increase in their number leads to lower production and financial results of industrial organizations.

The relationship between the profit per standard unit sales and the main types of industrial machinery will be as follows:

$$
Z=f(X ; Y)=42.542-0.007 X+0.66 Y
$$

with constraints $X \in(12.86 ; 6700), Y \in(10 ; 2700)$;

$$
Z=f(X ; Y)=-131.086+0.635 X+0.738 Y
$$

with constraints $X \in(178 ; 670), Y \in(36 ; 366)$, where $Z$ - profit per standard unit of sales, mln rub.; $X$ - load per plasma unit "Agat", that is; $Y$ - load per plasma unit "Pella", tons

Graphically, the relationship between the profit per standard unit of sales and technical resources is shown in Fig. 7. The coefficient of determination, given in brackets, showing a significant relationship between the study variables. 


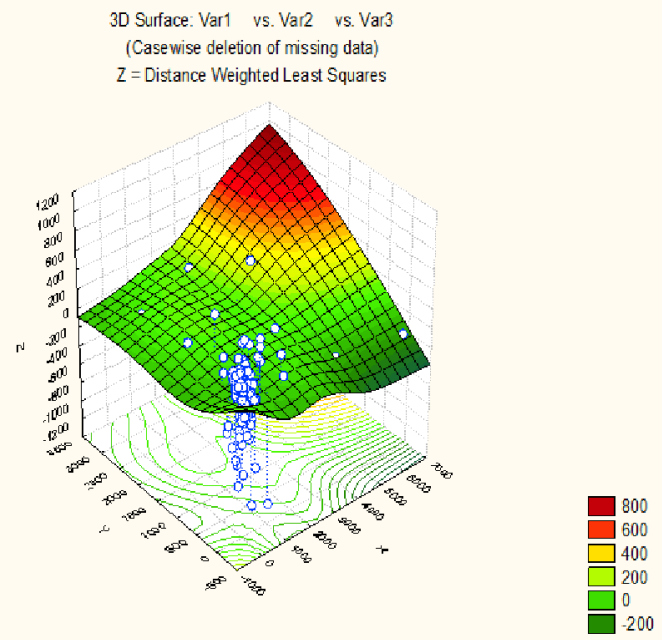

Chelyabinsk region

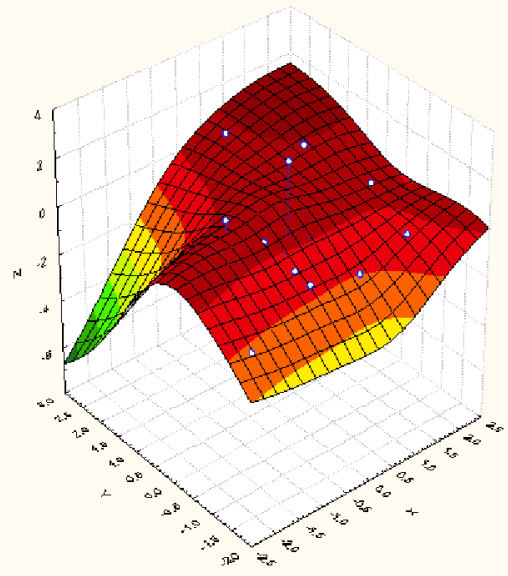

Sverdlovsk region

Fig. 7. Linear regression technical resources and profit per standard unit of sales (Note: $\mathrm{Z}$ - profit per standard unit of sales mln rub.; $X$ - load on one plasma unit "Agat", that is; $Y$ - load on one plasma unit "Pella", tons).

In Fig. 7 clearly shows that the presence of the load on the plasma unit "Agat" or plasma unit "Pella" in the park the main types of equipment for industrial companies leads to an increase in the results of their productive activity.

High $\left(\mathrm{R}^{2} \geq 90.5 \%\right)$ value of the coefficient of correlation between the final performance indicators (revenue, profit, production capacity) and the load on one of the main types of equipment allows to forecast specific independent variables. scatter plot for one variable - load on one plasma unit "Agat", where the dependent variable production capacity stands at comparable prices. Similar charts describe the dependence of revenues, profits from the sale of products on a single plasma unit "Agat" and one plasma unit "Pella".

Table. 5 shows the single-factor regression equation for scattering of variables with a confidence level of $90.5 \%$.
Table 5. Regression Equations (forecast) of individual variables.

\begin{tabular}{|c|c|}
\hline Regression equations & $\begin{array}{c}\text { The correlation coefficient } \\
\left(\mathrm{R}^{2}\right)\end{array}$ \\
\hline \multicolumn{2}{|c|}{ Chelyabinsk region } \\
\hline $\mathrm{Y}_{1}=0.058-0.05 \mathrm{X}_{1}$ & 0.905 \\
\hline $\mathrm{Y}_{1}=0.658+0.164 \mathrm{X}_{2}$ & 0.955 \\
\hline $\mathrm{Y}_{2}=0.037+0.074 \mathrm{X}_{1}$ & 0.807 \\
\hline $\mathrm{Y}_{2}=0.043+0.204 \mathrm{X}_{2}$ & 0.895 \\
\hline $\mathrm{Y}_{3}=-0.013+0.037 \mathrm{X}_{1}$ & 0.734 \\
\hline $\mathrm{Y}_{3}=-0.013+0.045 \mathrm{X}_{2}$ & 0.741 \\
\hline \multicolumn{2}{|c|}{ Sverdlovsk region $^{2}$} \\
\hline $\mathrm{Y}_{1}=0.374+0.533 \mathrm{X}_{1}$ & 0.933 \\
\hline $\mathrm{Y}_{1}=0.39+0.771 \mathrm{X}_{2}$ & 0.971 \\
\hline $\mathrm{Y}_{2}=0.415+0.493 \mathrm{X}_{1}$ & 0.893 \\
\hline $\mathrm{Y}_{2}=0.43+0.682 \mathrm{X}_{2}$ & 0.882 \\
\hline $\mathrm{Y}_{3}=0.179+0.433 \mathrm{X}_{1}$ & 0.733 \\
\hline $\mathrm{Y}_{3}=0.159+0.43 \mathrm{X}_{2}$ & 0.730 \\
\hline
\end{tabular}

This confirms the close relationship between the analyzed variables.

\section{Conclusion}

The analysis suggests the following conclusions.

1. The amount of plasma systems "Agat" has no direct impact on the efficiency of production of industrial organizations. Thus, the detection of the functional dependence of the production capacity at constant prices by the amount of productive resources plasma systems "Agat" in the regression equation is not reflected.

2. The hypothesis of the existence of a strong connection between the specific indicators as well as between the relative values of these parameters (growth rate) was not confirmed.

3. It was found that the results of production activities affect the technical capacity of power generation capacity.

4. There is a significant relationship between the type of the number of purchased units of plasma "Pella" and economic indicators of the efficiency of industrial production - revenue and profit from the sale of products. According to the plasma unit "Agat" such a connection has not been revealed.

The work was supported by Act 211 Government of the Russian Federation, contract № 02.A03.21.0011

\section{References}

1. N.A. Vasiliev, The messenger of the Saratov State Socio-Economic University, 4, 78-82 (2012)

2. V.V. Syroizhko, A.A. Andreev, A.A. Solyannikova, Gazette Saratov State Socio-Economic University, 9-10, 323-329 (2012)

3. I.V. Gontareva, Vestnik of SSU: a series of "Economy", 4, 133-139 (2011)

4. V. Denisyuk, The Economist, 5, 76-81 (2004) 
5. S. Koverga, A.S. Peredreeva, S.P. Kuzmenko, Marketing and Management of Innovations, 4, 2, 205-209 (2011)

6. A. Korenkov, Managing business growth potential: a monograph (GROTTO, 2004)

7. B.M. Mizyuk, Economics and Management, 3, 3139 (2001)

8. A.N. Polozova, L.V. Bryantseva, D.N. Hrohordin, Audit and Financial Analysis, 4, 360-369 (2008)

9. T.N. Prizhigalinskaya, D.S. Ternovskiy, The messenger of the Belgorod University of Cooperation, the housekeeper and the right, 1, 30-35 (2012)

10. N. Serebryakov, N.V. Grishchenko, PES Finance. Economy. Strategy, 3, 55-59 (2012)

11. V.V. Syroizhko, M.A. Voronov, I.I. Kulneva, Audit and Financial Analysis, 1, 142-145 (2014)

12. Electronic textbook according to the statistics StatSoft. www.StatSoft.ru/ home/ textbook/.

13. Zhukovskaya Century Meters, I.B. Muchnik, Factor analysis in socio - economic research (Statistics, Moscow, 1976)
14. K. Iberia, Factor analysis (Statistics, Moscow, 1980)

15. D. Lawley, A. Maxwell, Factor analysis as a statistical method (Mir, Moscow, 1967)

16. Ya Perch, Factor analysis (Statistics, Moscow, 1974)

17. A. Byul, P. Cepel, SPSS: the art of information processing. The analysis of statistical data and restore hidden patterns (Diasoftyup, St. Petersburg, 2001)

18. B. Markin, Analiz qualitative features and structures (Statistics, Moscow, 1980)

19. A. Kolemaev, N. Kalinina, Theory of probability and mathematical statistics: a Textbook (UNITYDANA, Moscow, 2003)

20. L.A. Soshnikova, Tamashevich Century, the Website of the Year, M. Schaefer, Multivariate statistical analysis in Economics: Textbook (UNITY- DANA, Moscow, 1999)

21. E.V. Popov, I.B. Fominykh, E.B. Kisel, Statistical and dynamic expert systems, the PPM Chapot (Finance and statistics, 1996) 